\title{
ASPECTOS HISTÓRICOS DA GINÁSTICA ACROBÁTICA: UM ESTUDO DE CASO A PARTIR DA TRAJETÓRIA DE RICIERI PASTORI
}

\author{
Giovana V. de Sousa*, Eliana de Toledo.
}

\section{Resumo}

A Ginástica Acrobática (GACRO) apesar de se utilizar principalmente da acrobacia, um tema considerado antigo, é considerada nova como modalidade esportiva, assumindo esse cargo apenas em 1939 na antiga URSS, pode ser competitiva ou demonstrativa. Atualmente fomentada pela Confederação Brasileira de Ginástica e federações estaduais no país, mas o esporte parece ainda ser pouco desenvolvido em relação às outras modalidades ginásticas. Assim, o objetivo desse trabalho foi entender os aspectos históricos da GACRO a partir da trajetória do professor Ricieri Pastori, um dos principais precursores da modalidade no país, por meio de um método de depoimento oral. Os resultados apontam que a formação de Ricieri com imigrantes russos, sua prática em clubes e sua participação no Circo Tihany influenciou a GACRO brasileira, para o conhecimento e a difusão da modalidade a partir do conhecimento adquirido e oportunidades geradas como cursos, participação de eventos internacionais, promoção de eventos nacionais da modalidade.

\section{Palavras-chave:}

Ginástica Acrobática, História da Ginástica, História do Esporte.

\section{Introdução}

A Ginástica Acrobática (GACRO) é um desporto novo que se une a dança de solo e acrobacias, podendo ser demonstrativo ou competitivo (BORELLA, 2005). Possui confederação brasileira e federações estaduais como organizações fomentadoras, porém é evidente que a modalidade ainda é pouco promovida e possui pouca valorização na oferta de cursos, eventos, rubricas, recursos financeiros etc. em relação às outras modalidades gímnicas (SOUSA e TOLEDO, 2018). Neste cenário, identificou-se uma lacuna de produção relacionada aos aspectos históricos da modalidade, que se constitui como o objetivo desta pesquisa. Desse modo, objetivou-se identificar e tornar público os registros acerca da história da ginástica acrobática no Brasil, a partir da trajetória de um de seus maiores disseminadores e precursores, Ricieri Pastori, através da metodologia de história oral, com a técnica de depoimento oral.

\section{Resultados e Discussão}

Aspectos históricos da GACRO a partir da trajetória de Ricieri Pastori:

- Formação com imigrantes russos e lituanos;

- Prática no Clube Ginástico Paulista;

- Apresentações em programas de televisão;

- Participação do Circo Tihany;

- Participação/ Apresentação em eventos nacionais e internacionais: Gymnaestrada, festivais de dança;

- Falta de apoio das organizações fomentadoras com a modalidade.

- Criação da Lindagg (Liga Nacional de Desportos Acrobáticos e Ginástica Geral).

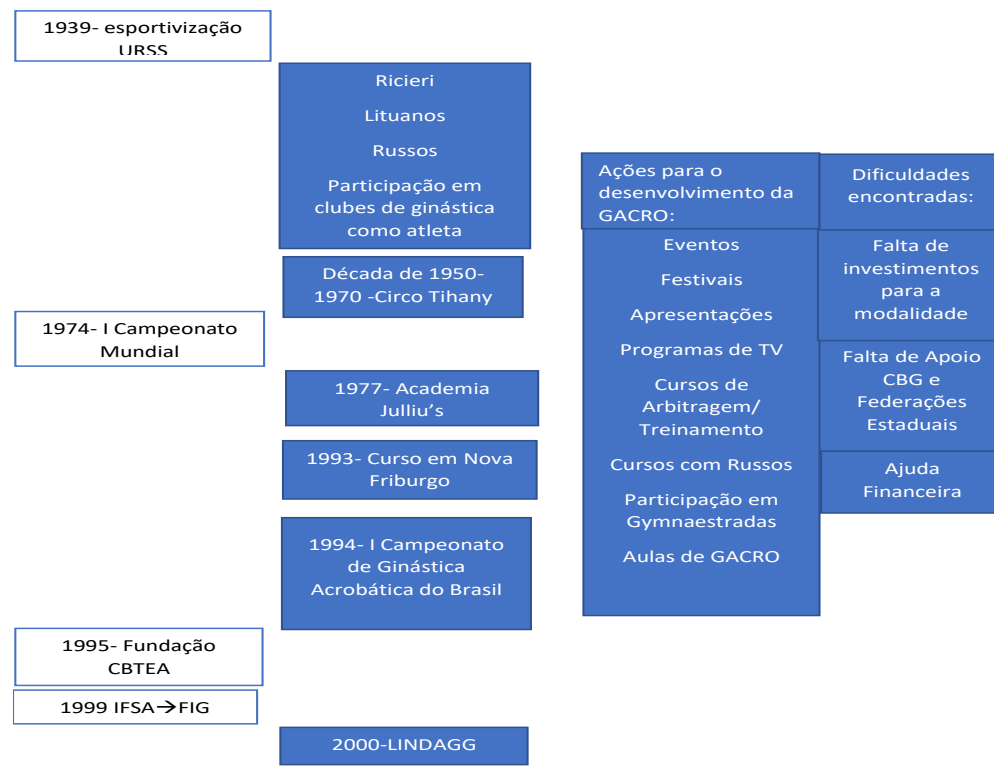

Conclusões

- Treinamento com russos e lituanos $\rightarrow$ maior conhecimento $\rightarrow$ apresentações em festivais $e$ programas de TV/ Circo Tihany $\rightarrow$ viagens, conhecimento e contatos;

- Cursos de treinamento e arbitragem de qualidade, com o objetivo de disseminar a prática. Gerando maior prática da modalidade;

- Surgimento de campeonatos e regulamentos.

\section{Agradecimentos}

Gostaria de agradecer ao Laboratório de Pesquisas e Experiências em Ginástica (LAPEGI), e a CNPq pela oportunidade dessa pesquisa.

SOUSA, G.V.; TOLEDO, E. Aspectos Históricos sobre o Desenvolvimento da Ginástica Acrobática no Estado de São Paulo. Rev Trab. Iniciaç. Cient. Unicamp, Campinas, v. 26, out. 2018. 